\title{
CEU
}

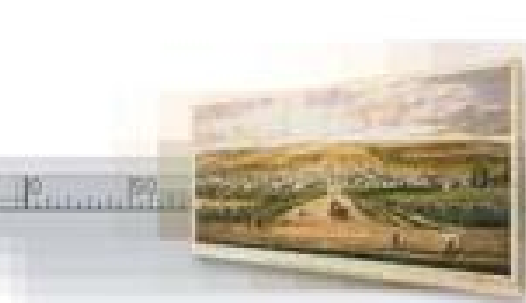

a

- Trabajo realizado por el equipo de la Biblioteca Digital de la Fundación Universitaria San Pablo-CEU 
Biographical Notes

Rafael Pampillón and José Luis Jimtere both are in the Institute de Empresa, $\mathrm{C} / \mathrm{m}^{2}$ de Molina, 1228006 Madrid, Spain.

\section{The Czech Republic: A Review of the Eastern European Economy with the Lowest Unemployment Rate}

by Rafael Pampillón and José Luis Jiménez

\section{Introduction}

In 1989, the people of Czechoslovakia ousted the communists from government after almost fifty years of rule, in a peaceful process known as the Velvet Revolution. An IMF-backed stabilisation programme was launched in 1991. It comprised some liberalisations, a sharp devaluation of the currency and the unification of the exchange rate. In 1992, the Czechs and Slovaks decided to separate, in what was known as the Velvet Divorce. The separation of the Czech and Slovak Republics officially took place the 1st of January 1993 without political and social crisis.

The state of the economy of the Czech Republic at the end of 1991, was as follows:
GDP per capita

GDP growth

CPI (\% change av.)

Unemployment rate

Source: EIU (1995).
Gross Domestic Product
$\$ 32,2$ billion

$\$ 2,129$

$-14.7 \%$

$57.8 \%$

$6.6 \%$
At the helm of government in the Czech Republic, was President Vaclav Havel, a playwright and dissident in the communist days, and Prime Minister Vaclav Klaus, a free-market reformer, who used to read his Milton Friedman under his desk in the communist days.

Due to the new economic situation GDP of the Czech Republic registered a negative growth of $-8,9 \%$ in $1992,0.9 \%$ in $1993,2.6 \%$ in 1994 , and for 1995 , the estimate is $4.0 \%$ (See Table 1). Per capita this figure rose from $\$ 2,712.8$ in 1991 to $\$ 4,375.8$ (estimate) in 1995 . Adjusting it for purchasing power parity (PPP), Czech per capita GDP is estimated at $\$ 8,200$ (See Table 2 ). This is the second highest in Eastern Europe, behind Slovenia's $\$ 9,000$ per capita (PPP). 


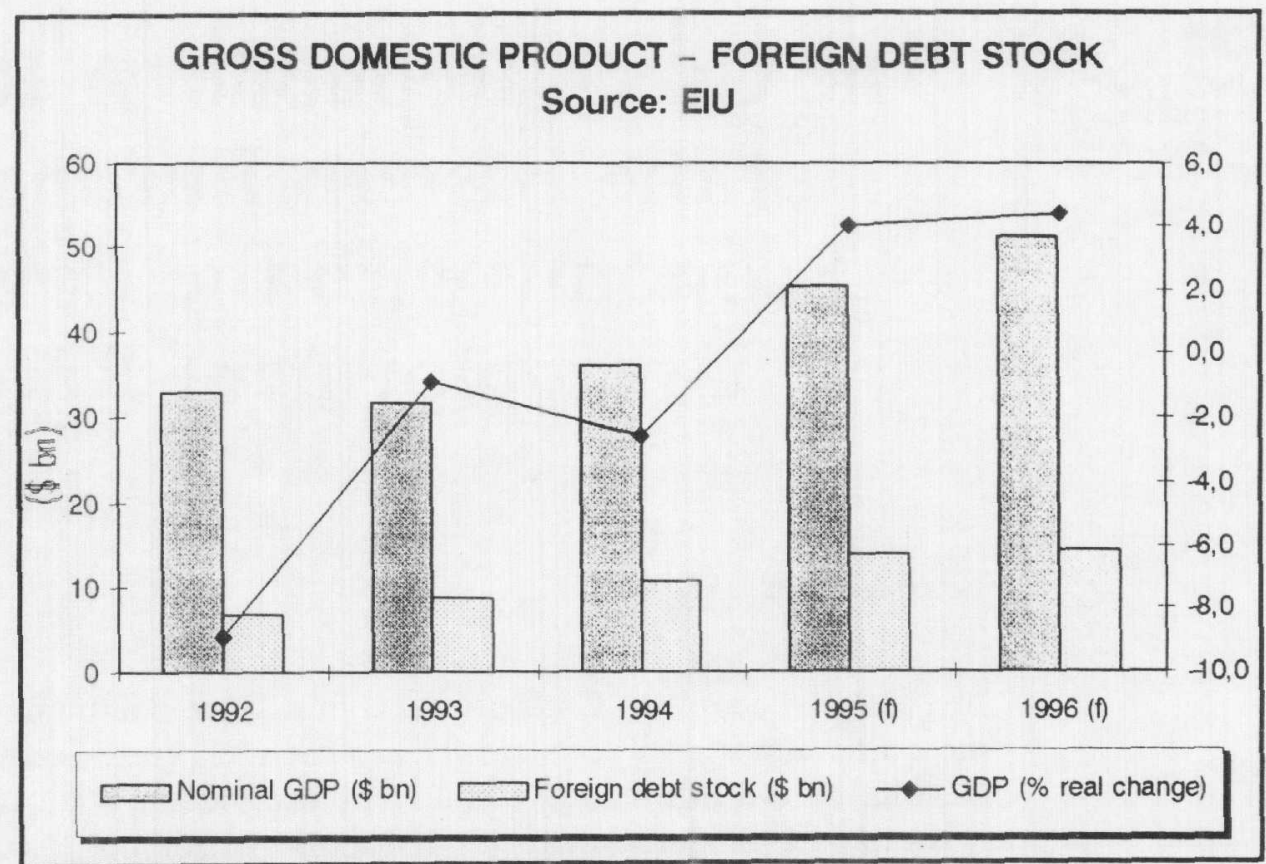

Fiscal Policy

After 1992 deficit of $1.8 \%$ of GDP, the Czechs maintained a balanced budget, registering a perfect balance in 1993 and a surplus of 2 Billion Czech crowns in 1994. In percentage of GDP, 1994 registered a surplus of $1 \%$, and by November 1995, the surplus was also $1 \%$ of GDP. The components of the budget are shown in Table 3 . Among twelve former communist countries, only the Czech Republic, Estonia and Latvia achieved a balance or a surplus in their budgets. The balance in the budget was achieved, largely by increase in tax collection, including the introduction of the VAT (value-added-tax) in 1993.

\section{CPI and Monetary Indicators}

The liberalisation of $90 \%$ of prices and of the foreign trade, inflation average rose to $57.8 \%$ in 1991 . But after this sharp acceleration and the introduction of value added tax in 1993, inflation was brought under control dropping to $10.0 \%$ in 1994 and $9.0 \%$ (estimate) in 1995 .

The prices increases (\% change av.) by sector for the year 1994 was as follows:

\begin{tabular}{|l|c|}
\hline Consumer prices & 18.0 \\
Food & 13.2 \\
Non-Food & 18.0 \\
Public Catering & 21.9 \\
Services & 25.3 \\
Industry & 11.4 \\
Building Industry & 25.9 \\
Transport (all types) & 29.5 \\
Communication services (sales) & 28.9 \\
Agricultural products & 6.2 \\
Source: Ministry of Industry and Trade, Czech Republic. & \\
\hline
\end{tabular}


Due to inflation is largely a problem in the supply side, the Czech National Bank has pursued a policy of continuous reduction of interest rates on domestic credits (loans) in order to promote economic growth. The Prague Interbank Offered Rate (PRIBOR) has steadily declined as is shown below.

Average interbank rate of interest from deposits (PRIBOR)

\begin{tabular}{|l|c|c|c|c|c|c|}
\hline No. of days & 1992 & 1993 & 1994 & (IQ) & IIQ & IIIQ \\
\hline 7 days & 10.50 & 10.74 & 7.97 & 7.31 & 7.58 & \\
\hline 90 days & 13.80 & 13.15 & 9.08 & & 8.43 & 8.40 \\
\hline 180 days & 14.60 & 13.95 & 9.21 & & 8.64 & 8.56 \\
\hline \multicolumn{7}{|l}{ Source: Ministry of Idustry and Trade, Czech Republic } \\
\hline
\end{tabular}

\section{Labor Policy}

The Czech goverment maintains a policy of not allowing wages to rise by more than five percent (5\%) above the CPI. The wages have, therefore, been kept low, relative to European Union rates. The average wages for general workers for 1995 were $\$ 315 /$ month. Compared to German wages, the wages of Czech workers were, on the average, $10 \%$ of German wages. (See Table 4.)

Unemployment in the Czech Republic has been kept low, with rates of $2.6 \%, 3.5 \%, 3.2 \%$ and $3.2 \%$ for the years $1992,1993,1994$ and 1995 respectively. Czech unemployment rates are one of the lowest among the Eastern European countries.

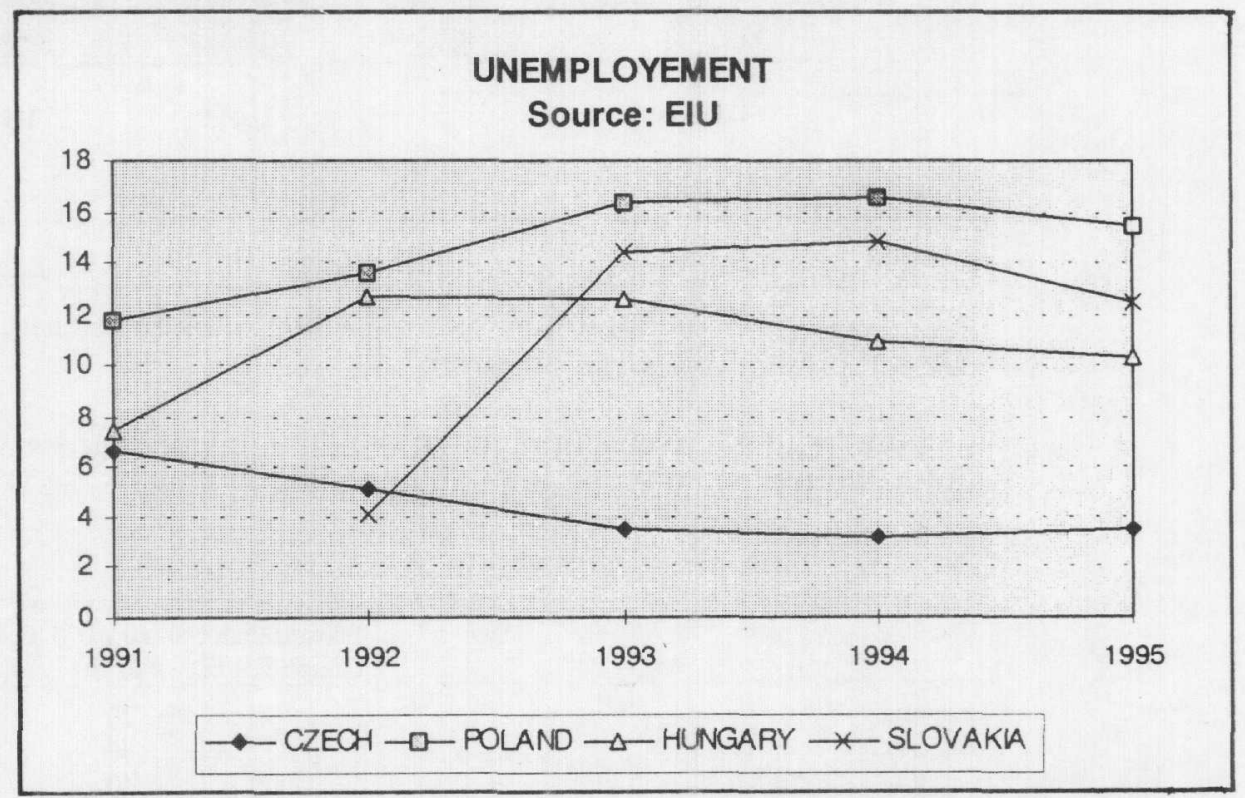

Although the Czech Republic has achieved low unemployment rates, there is a hidden structural defect in the economy. As Dirk Damrau, Director of Salomon Brothers International points out, the investors in the privatised companies of the Czech Republic are passive investors. They have not done the restructuring required, which would lead to downsizing to make the Czech 
companies more competitive (Central European Economic Review, September 1995, p. 6). This may explain why Czech industrial output is not as high as that of Poland and Hungary, which have undergone restructuring.

\section{Privatisation}

The intensive process of privatisation represented the most important feature of the Czech economy. In 1993 small-scale privatisation was practically completed, with 24,359 companies privatised by means of auctions by the end of 1993. This provided the government with 31 Billion Czech crowns in revenues. In the industrial sector, 13,500 companies were privatised, realizing for the government, 19 Billion Czech crowns in revenues.

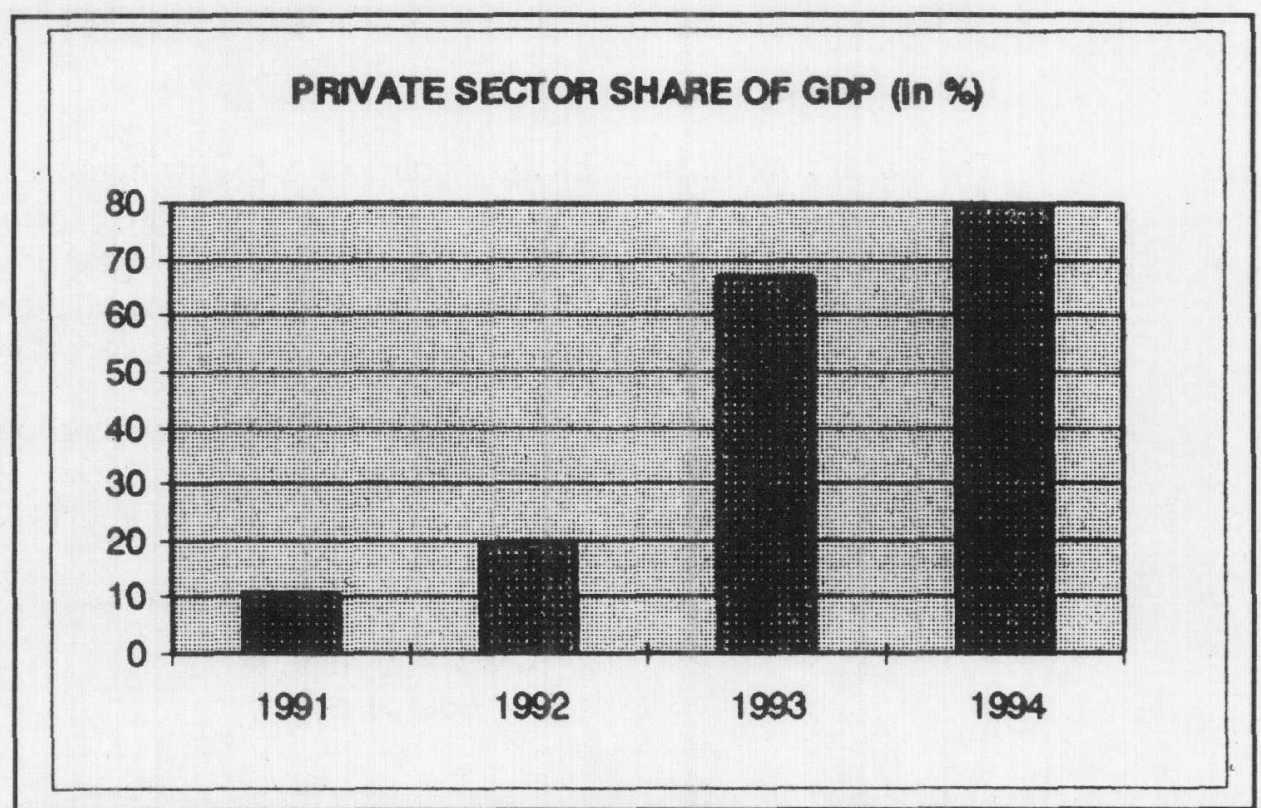

All told, privatisation realized 212.5 Billion Czech crowns for the year 1992, and for 1993, total revenues amounted to 155 Billion, of which 87.8 Billion represent industrial property.

As a result of privatisation, the share of the private sector in GDP formation reached $80.0 \%$ in 1994 , from a low of $10.6 \%$ in 1990 .

Comparative progress in transition in eastern Europe:

\begin{tabular}{|l|c|}
\hline Country & $\begin{array}{c}\text { Private sector share of GDP. Mid-94 in \% } \\
\text { (rough EBRD estimate) }\end{array}$ \\
\hline Albania & 50 \\
Bulgaria & 40 \\
Croatia & 40 \\
Czech Republic & 65 \\
Hungary & 55 \\
Poland & 55 \\
Romania & 35 \\
Slovak Republic & 55 \\
Slovenia & 30 \\
\hline
\end{tabular}




\section{Investment}

Total Foreign Direct Investment (FDI) in the Czech Republic from 1990 to Nov. 1995 has reached a total of $\$ 5.27$ Billion. The distribution of the investments by country and sector are as follows:

\begin{tabular}{|l|c|c|}
\hline Country & 1993 & $1990-1994$ \\
\hline Germany & 82 & 790 \\
USA & 255 & 651 \\
France & 34 & 339 \\
Belgium & 32 & 188 \\
Austria & 55 & 201 \\
Others & 103 & 530 \\
TOTAL (in million US\$) & 567 & 2699 \\
\hline Source: Ministry of Industry and Trade, Czech Republic \\
\hline
\end{tabular}

Foreign Direct Investment by sector (in million US\$)

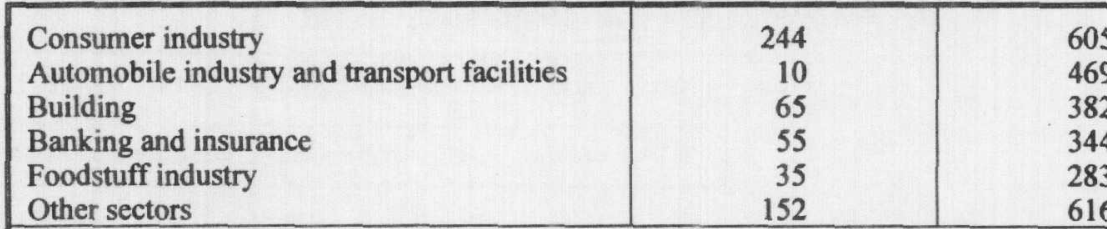

Source: Ministry of Industry and Trade, Czech Republic

The foreign investments come in three forms, direct purchase of Czech companies, portfolio investments by investment funds in the form of shares of stock and other securities bought in the Prague Stock Exhange, and financial credits obtained by Czech companies from sources abroad.

Investment in shares and securities quoted in the Prague Stock Exchange reached $\$ 350$ Million in 1993. Financial credits to Czech companies were $\$ 300$ Million and \$800 Million for 1992 and 1993 respectively.

The stable political conditions and a relatively low inflation rate have maintained investor confidence in the Czech Republic. This confidence is reflected in the upgrading by Standard and Poor $^{2} \mathrm{~s}$ of Czech risk rating from $\mathrm{BBB}+$ to $\mathrm{A}$.

\section{Balance of Payments}

The Czech Republic has registered deficits in the trade balance since 1991 except for 1993. The current account balance has followed the same way, registering a \$201 million superavit in 1993 and -50 million in 1994, due to the balance of services (transfer of gas and tourist industry) and transfers and remittances of foreign exchange by both individuals and corporations. Table 6 compares Czech trade balances with other Eastern European countries. 
As we have pointed out above, the tourism industry is a vital component in the Czech Republic's balance of payments. Tourist arrivals in 1994 reached. 17 million, generating revenues of $\$ 1.97$ Billion. This figure is equivalent to $14 \%$ of export receipts and $5.6 \%$ of GDP.

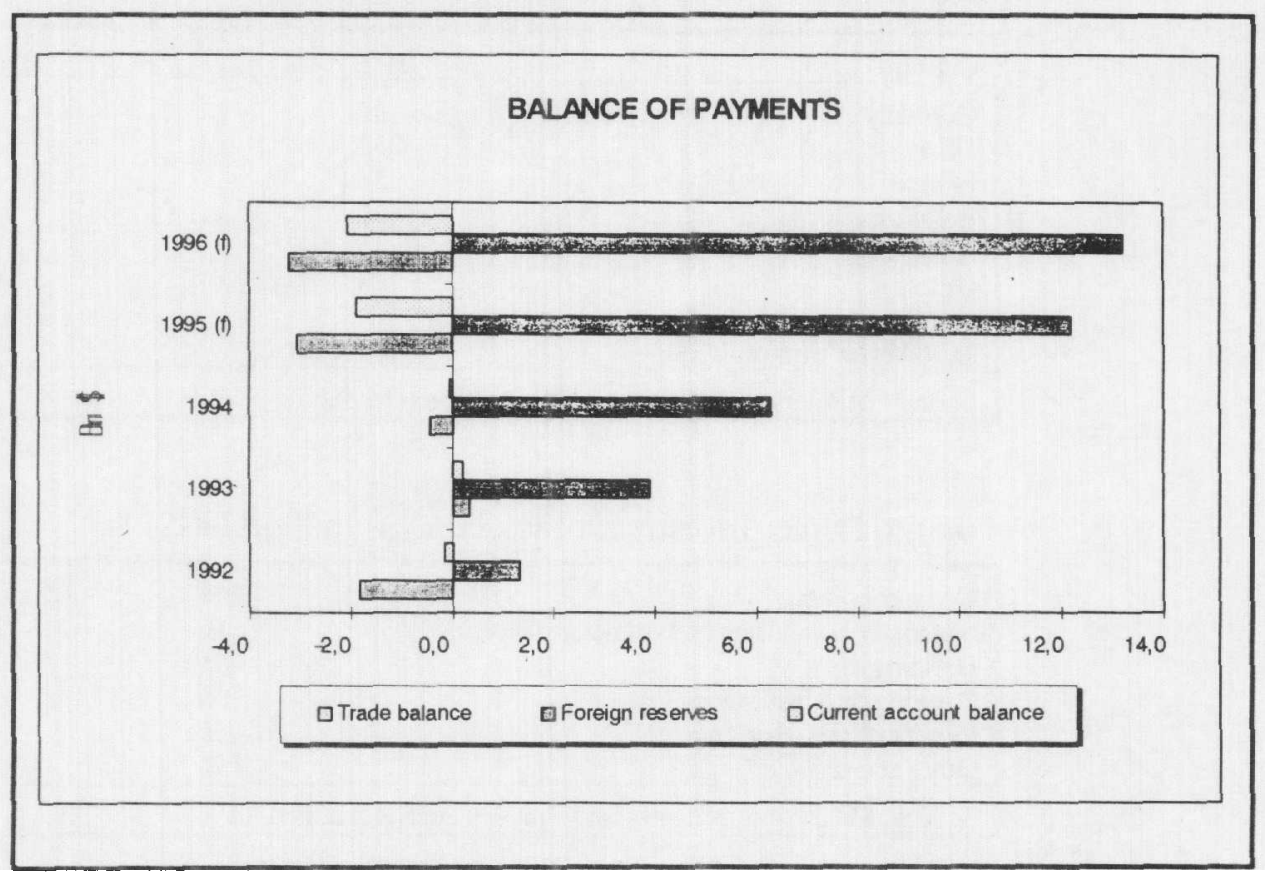

The number of tourist arrivals and revenues generated for the years 1992 - 1994 as compared to other countries are as follows:

\begin{tabular}{|l|c|c|c|}
\hline \multicolumn{4}{|c|}{ Rank by receipts } \\
\hline Country & $(85)$ & $(94)$ & 1994 receipts (\$ B) \\
\hline USA & 1 & 1 & 57.10 \\
France & 4 & 2 & 25.00 \\
Austria & 6 & 6 & 13.16 \\
Poland & 74 & 15 & 6.15 \\
Czech Republic & 54 & 31 & 1.97 \\
Hungary & 56 & 39 & 1.44 \\
\hline \multicolumn{4}{|l|}{ Source: World Trade Organization } \\
\hline
\end{tabular}

\begin{tabular}{|l|c|c|c|}
\hline \multicolumn{4}{|c|}{ Rank by arrivals } \\
\hline & $(85)$ & $(94)$ & 1994 arrivals (m) \\
\hline France & 1 & 1 & 60.64 \\
USA & 3 & 2 & 46.43 \\
Hungary & 11 & 5 & 21.43 \\
Austria & 5 & 8 & 17.89 \\
Poland & 22 & 9 & 17.60 \\
Czech Republic & 16 & 10 & 17.00 \\
\hline \multicolumn{2}{|l|}{ Source: Ministry of Industry and Trade, Czech Republic } \\
\hline
\end{tabular}

The key objective of the maintenance of a stable koruna followed by the monetary authorities it could not be easy to follow in the future. After an initial 
sharp devaluation at the start of the reform in 1991, the rate was fixed to a basket of western currencies (65\% D-mark and 35\% \$US). Despite it has been stable in nominal terms, due to the inflation differential with this countries and high capital inflows, in real terms it has risen significantly since then. This situation is making a policy dilemma to the goverment because it has no much sense to maintain an appreciated currency with trade and current account deficit, as IMF has pointed out recently.

\section{External Debt}

During the $80^{\prime} \mathrm{S}$, the prudent management of the external debt by the czech authorities (they did not apply for external debt to resolve their domestic problems), has permitted the country to confront the changes to a market economy without a high mortgage. In 1991, In 1991, gross external debt stood at $7.2 \$ \mathrm{bn}$. (22\% of GDP) and the foreign debt service reached $\$ 1,1 \mathrm{bn}$. (less than $10 \%$ ). At the end of 1995, total external debt represented $\$ 14$ billions ( $31 \%$ of GDP), while the debt service reached $\$ 2$ billions ( $9.9 \%$ of export). These figures are well below from Poland and Hungary where the total stock debt represented $(36,7 \%$ and $68,4 \%$ of GDP) respectively.

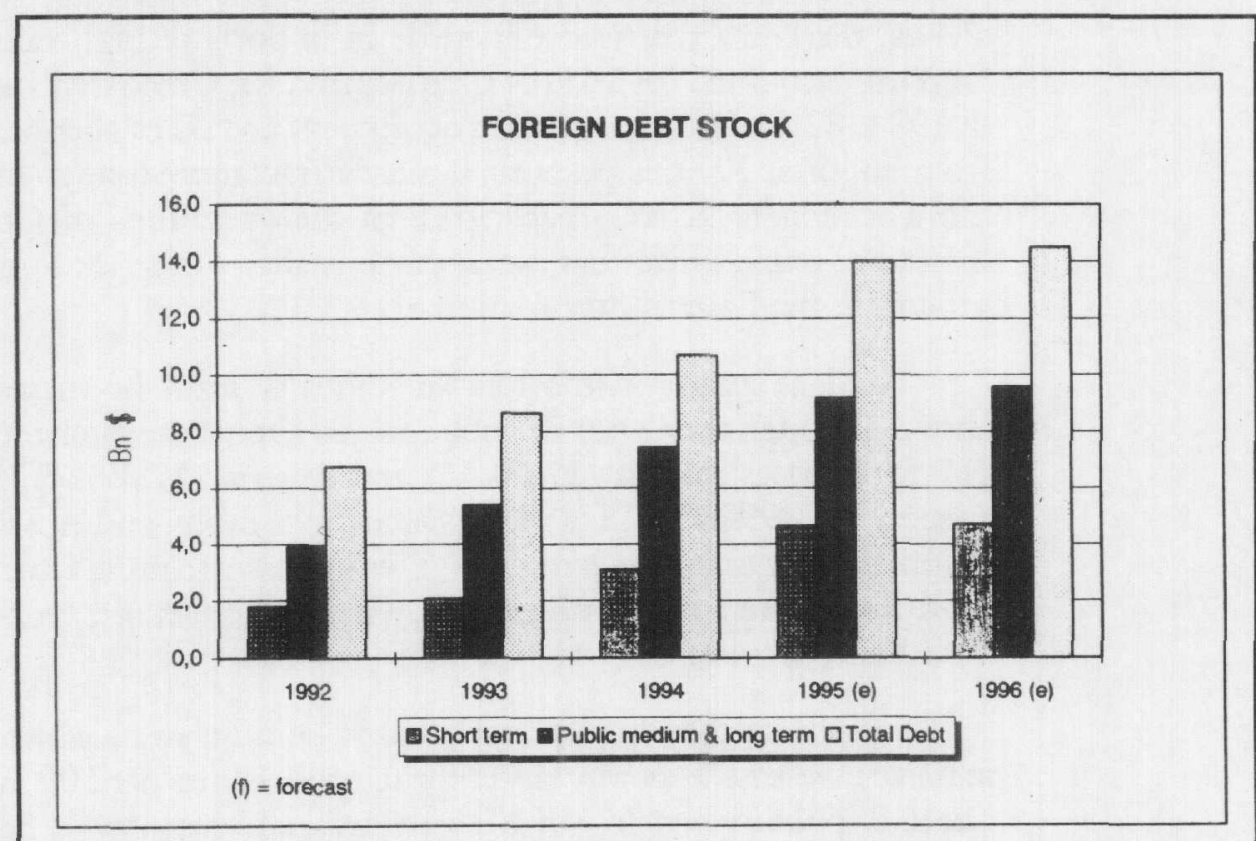

\section{Conclusion:}

All indications for 1995 show that the Czech Republic has managed its economy above average. Estimates for 1995 show that GDP could reach $\$ 45.2$ billion. GDP per capita could reach $\$ 4,375.8$, and growth could be about $4.0 \%$. Inflation is a single digit $9.0 \%$ and unemployment would continue to be low (3.2\%). 
The success of the Czech economy can be seen from the fact that it has been admitted recently to the Organization for Economic Cooperation and Development. Although admission to the OECD does not bring economic advantages like admission to the EU, it does bring prestige, and indicates that the Czechs have been accepted into the supposed rich boys' club of the nations of the world.

Some challenges have to be met, however, if the Czech Republic intends to maintain its good economic performance.

First, they must continue with structural reforms, giving to the private sector an increasing role. A full restructuring must be made of Czech industry, which is still outmoded and inefficient by European standards. The industrial output, which is in a decline, should be benefit from this. Growth in the Czech industrial output for 1995 (Jan. To Nov.) does not compare favorably with that of Slovenia (12.0\%), Poland (14.9\%), Hungary (7.9\%) and even Bulgaria $(5.3 \%)$, which are all experiencing increases in industrial output.

Second, the Czech economy must also endeavor to produce more highvalue-added products, not only for the domestic market, but for export, if it wishes to achieve the high growth levels of the Asian tigers. But as Table 7 shows, there is a worrisome increase in imports of high-value-added goods. Imports accounted for $94 \%$ of total demand for Czech demand for computers in $1994.82 \%$ of communication equipment and 62 of chemicals were sourced from imports. For this purpose, it must attract more foreign investors who are more willing to actively participate in the operations of Czech companies, instead of passive investors, who only buy shares of stock to benefit from the growth in the Eastern European markets.

Third, revenues in the tourism industry must be increased. As shown above, although the Czech Republic hosted almost the same number of tourists (17 Million) as Poland $(17.60 \mathrm{M})$ and Austria $(17.89 \mathrm{M})$, Poland's tourist receipts for 1994 ( $\$ 6.15 \mathrm{~B}$ ) were three times more, and Austria's (\$13.16 B) six times more than Czech receipts. This indicates that the Czech Republic host more backpackers than businessmen, who on the average, spend twice as much as ordinary tourists.

To achieve this, infrastructure must be improved, which would require massive investment. For instance, the telephone lines per 100 inhabitants in the Czech Republic is very low by EU standards, and even low by Eastern European standards. Without telecommunications advances, the Czech Republic will not be able to attract the high-spending business tourists.

Another area for improvement is roads, which have been overburdened by traffic. A Berlin executive, for instance, travelling to Dresden, would spend half the time it takes to travel to Prague, even though the distance from Berlin to Dresden is 1.5 times the distance from Berlin to Prague.

The factors that led to the success of the Asia "tigers" are export-oriented growth, high domestic savings, low inflation, high foreign investments, and 
low labor costs (Pamillon 1995) The Czech Republic has been able to achieve low inflation rates and has attracted high foreign investments. It has been able to play the game of low wages played by the Asian economies. What is lacking in this menu, however, is high growth led by exports.

The Czech GDP growth is only one-half the growth rate of the Asian tigers, which they have maintained for more than ten years. Czech exports are low, and its trade balance has been negative since 1991. If these two components can be added (high exports and high growth), perhaps we shall see the emergence of the firtst Eastern European tiger. 
Table 1

Key Czech Economic Indicators

\begin{tabular}{|l|c|c|c|c|}
\hline & 1992 & 1993 & 1994 & 1995 (est.) \\
\hline GDP (\$ Billion) & 28.0 & 31.2 & 36.0 & 45.2 \\
GDP per capita (\$) & $2,712.8$ & $3,023.9$ & $3,486.5$ & $4,375.8$ \\
GDP (annual growth) & $-6.4 \%$ & -0.9 & 2.6 & 4.0 \\
CPI (\% change av.) & 11.1 & 20.9 & 10.0 & 9.0 \\
Unemployment rate & $2.6 \%$ & $3.5 \%$ & $3.2 \%$ & $3.2 \%$ \\
Current Account (\$B) & -0.3 & 0.1 & 0.0 & -1.9 \\
Current Account (\% of GDP) & -1.1 & 0.3 & 0.0 & -4.2 \\
\hline Source: OECD & & \\
\hline
\end{tabular}

\begin{tabular}{|l|c|}
\hline \multicolumn{2}{|c|}{ Table 2 } \\
\hline Country & GDP/capita at PPP (1994) \\
\hline Slovenia & $\$ 9,800$ \\
Czech Republic & $\$ 8,200$ \\
Estonia & $\$ 7,000$ \\
Slovaki & $\$ 6,800$ \\
Hungary & $\$ 6,600$ \\
Poland & $\$ 5,600$ \\
Croatia & $\$ 5,000$ \\
Latvia & $\$ 4,800$ \\
Russia & $\$ 4,600$ \\
Bulgaria & $\$ 4,000$ \\
Lithuania & $\$ 3,400$ \\
Romania & $\$ 3,100$ \\
\hline
\end{tabular}




\begin{tabular}{|c|c|c|c|c|c|c|}
\hline \multicolumn{7}{|c|}{ Table 3} \\
\hline \multicolumn{7}{|c|}{ The State Budget for 1994} \\
\hline \multicolumn{2}{|r|}{$\begin{array}{l}\text { Basic structure of the state budget revenues in } \\
\text { billion Czech Korunas) }\end{array}$} & & 1993 & & 1994 & \\
\hline $\begin{array}{l}\text { A. } \\
\text { B. } \\
\text { C. }\end{array}$ & $\begin{array}{l}\text { Revenues from taxes } \\
\text { Revenues from social security } \\
\text { Revenues other than taxes }\end{array}$ & & $\begin{array}{r}223.6 \\
107.5 \\
22.2 \\
\end{array}$ & & $\begin{array}{r}237.3 \\
120.1 \\
24.4\end{array}$ & \\
\hline \multicolumn{2}{|c|}{ TOTAL REVENUES } & & & 353.3 & & 381.8 \\
\hline \multicolumn{7}{|c|}{ LOCAL BUDGET REVENUES } \\
\hline $\begin{array}{l}\text { A. } \\
\text { B. } \\
\text { C }\end{array}$ & $\begin{array}{l}\text { Revenue from taxes } \\
\text { Revenues other than from taxes } \\
\text { Total own revenues } \\
\text { Transfer from state budget }\end{array}$ & 26.1 & $\begin{array}{l}33.7 \\
14.5 \\
48.2\end{array}$ & 25.1 & $\begin{array}{l}39.0 \\
25.1 \\
77.1\end{array}$ & \\
\hline \multicolumn{2}{|c|}{ TOTAL REVENUES } & & & 74.3 & & 77.1 \\
\hline \multicolumn{7}{|c|}{ STATE BUDGET EXPENSES } \\
\hline A. & $\begin{array}{l}\text { Ordinary current expenses } \\
\text { non-investment subsidies to corporations } \\
\text { transfer to households } \\
\text { public consumption - population } \\
\text { public consumption - state } \\
\text { debt service } \\
\text { transfers to foreign countries } \\
\text { housing policy } \\
\text { allocations (subsidies) to local budgets }\end{array}$ & & $\begin{array}{r}314.8 \\
29.8 \\
121.4 \\
63.6 \\
64.1 \\
15.6 \\
0.9 \\
2.2 \\
17.0 \\
\end{array}$ & $\begin{array}{l}0.9 \\
4.7\end{array}$ & $\begin{array}{r}336.7 \\
28.0 \\
139.6 \\
68.2 \\
81.1 \\
0.0 \\
\\
\\
14.0\end{array}$ & \\
\hline B. & $\begin{array}{l}\text { Capital expenses } \\
\text { subsidies to corporations } \\
\text { subsidies to public sector }\end{array}$ & $\begin{array}{r}31.5 \\
5.8 \\
25.7 \\
\end{array}$ & 6.4 & $\begin{array}{r}35.9 \\
29.5 \\
\end{array}$ & & \\
\hline C. & Government credits/loans & 7.3 & & & 7.4 & \\
\hline \multicolumn{2}{|c|}{ TOTAL EXPENSES } & & 353.3 & & 379.8 & \\
\hline \multicolumn{7}{|c|}{ Source: Ministry of Trade and Industry, Czech Republic } \\
\hline
\end{tabular}

\begin{tabular}{|l|c|}
\hline \multicolumn{2}{|c|}{ Table 4 } \\
\hline Wage Costs (as \% of German gross wages, 1994 levels) \\
\hline Country \\
\hline Slovenia \\
Hungary & $31.0 \%$ \\
Poland & $13.0 \%$ \\
Czech Republic & $10.5 \%$ \\
Slovakia & $10.3 \%$ \\
\hline Source: J. P. Morgan & $8.5 \%$ \\
\hline
\end{tabular}

\begin{tabular}{|l|c|c|c|}
\hline \multicolumn{4}{|c|}{ Trable 5 } \\
\hline & 1993 & 1994 & 1995 \\
\hline Czech Republic & 705 & -1170 & -660 \\
Poland & -1340 & -4430 & -4040 \\
Slovakia & -140 & -255 & -750 \\
\hline Source: Investmentbank Austria & & \\
\hline
\end{tabular}


Table 6

Import Penetration in the Czech Republic ( $\%$ of sectors provided by imports, 1994 )

\section{Computers}

Communication equipment

Optical, medical equipment

Chemicals

Machinery

Furniture

Cars, trailers

Leather, shoes

Oil, Coal

Tobacco

Metal

Electrical machines

Textiles

Wooden products

Printing and Publishing

Foodstuffs

Source: Czech Statistical Office

\section{Bibliography}

The Economist Group, Business Central Europe, June 1995

The Economist Group, Business Central Europe, July/August 1995

The Economist Group, Business Central Europe, September 1995

The Economist Group, Business Centrai Europe, October 1995

The Economist Group, Business Central Europe, November 1995

EBRD. Transition Report. October 1994.

EBRD. Measuring Transition. Extracts from the Transition Report 1994.

Joint Ventures Club. Conditions for Business Activities of Foreign Investors in the Czech Republic, Third Edition, Prague, January 1995

Ministry of Industry and Trade, Czech Republic, 1994. Analysis of economic development in the Czech Republic and in MIT organizations in 1993.

Ministry of Industry and Trade, Czech Republic, doing Business in the Czech Republic, January 1995

Pampillón, Rafael, Instituto de Empresa, 1995, Polonia, El Pais de Europa con el Mayor Crecimiento 1993. 